\title{
IMPLEMENTASI METODE TAKRIR DALAM MENGHAFALKAN AL QURAN BAGI SANTRI PONDOK PESANTREN PUNGGUL NGANJUK
}

\author{
Mughni Najib \\ Program Studi Pendidikan Agama Islam Pascasarjana IAIT Kediri \\ mugnin@gmail.com
}

\begin{abstract}
Abstrak.
Penelitian ini dilatarbelakangi oleh banyaknya keluhan dari teman-teman baik yang sedang menghafal Al-Qur'an maupun yang sudah hatam Al-Qur'an. Mereka merasa kesulitan dalam menghafal dan melancarkan Al-Qur'an. Oleh karena itu perlu penerapan metode Takrir dalam menghafal Al-Qur'an yang mana metode ini adalah sebagai upaya memperbaiki, menjaga hafalan yang sudah pernah dihafal agar tetap melekat dalam hati. Berdasarkan latar belakang di atas ,maka dapat di ambil rumusan masalah, bagaimana proses implementasi metode Takrir dalam menghafal Al-Qur'an dan apa hasil Yang di capai dalam implementasi metode Takrir dalam menghafal Al-Qur'an dan bagaimana praktek evaluasinya. Dalam peneliti ini menggunakan metode diskriptif kualitatif dengan pendekatan fenomenologi. Sementara teknik pengumpulan data penggunaan metode interview, observasi dan dokumentasi. Sedangkan dalam menganalisis data penulis menggunakan tiga tahapan diantaranya, reduksi data, display data dan penarikan kesimpulan. Hasil penelitian menunjukkan: Pertama, Secara keseluruhan Proses implementasi metode Takrir dalam menghafal Al-Qur'an di pondok pesantren Punggul Bagor Nganjuk sudah berjalan dengan baik, hal ini berdasarkan pada adanya realita bahwa seluruh proses penerapan menghafal Al-Qur'an telah dilaksanakan dengan menggunakan metode Takrir. Namun masih belum sempurna, terlihat dengan adanya beberapa problem-problem yang di hadapi. Kedua, Hasil yang telah di capai dari penerapan metode Takrir terbilang baik dan berhasil, indikasinya adalah sebagian besar santri tahfidz dapat menghafal setengah Juz ayat- ayat Al-Qur'an perbulan, itu telah memenuhi target lembaga. Adapun kaitannya dengan mengevaluasi pengimplementasian metode Takrir akan di lakukan musyawarah yang berjenjang yaitu setiap 2 atau 3 bulan sekali sesuai dengan kebutuhan,hal tersebut di lakukan untuk mengetahui tarjet - tarjet pondok yang telah di dapat dan target-target pondok yang belum tercapai sehingga untuk memecahkannya membutuhkan musyawarah yang berkala dan konsisten selain itu musyawarah ini bertujuan untuk menemukan gagasangagasan baru untuk kemajuan pondok.
\end{abstract}

\section{Kata Kunci : Implementasi Metode Takrir, Menghafal Al-Qur'an}

\section{Pendahuluan}

Al-Qur'an sebagai kitab suci yang menjadi pedoman hidup bagi setiap muslim. Berbeda dengan kitab suci yang lain, maka Al-Qur'an adalah kitab suci yang keaslian dan kemurniannya telah dijamin oleh Allah SWT, yang tidak akan mengalami perubahan, penambahan maupun pengurangan, tidak ada satu hurufpun bergeser atau berubah dari tempatnya, tidak satu huruf atau katapun yang mungkin dapat disisipkan oleh siapa pun kedalamnya.

Sebagaimana masalah rizqi, kedudukan dan pangkat adalah dari Allah SWT. Demikian juga kemurnian Al-Qur'an adalah telah menjadi Sunnatullah, bahwa Allah telah memberikan rizqi, pangkat kepada seseorang biasanya melalui manusia, maka demikian juga Allah SWT, memelihara dan menjaga kemurnian AlQur'an ini pun melalui manusia yaitu 
dengan cara memberikan kemudahan kepada orang-orang yang dikehendaki untuk menghafal Al-Qur'an.1Sebagaimana Firman Allah SWT

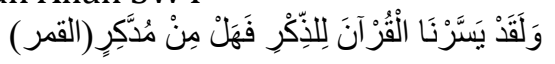

Terjemahanya: Dan Sesungguhnya telah Kami mudahkan Al-Qur'an untuk pelajaran, Maka Adakah orang yang mengambil pelajaran ( Al-Qomar : 17$){ }^{2}$

Dengan demikian orang-orang yang hafal Al-Qur'an pada hakikatnya adalahorang - orang pilihan yang sengaja dipilih oleh Allah untuk menjaga dan memeliharakemurnian Al-Qur'an, dalam hubungan ini Allah berfirman: kemudian kitab itu Kami wariskan kepada orangorang yang Kami pilih di antara hambahamba Kami, lalu di antara mereka ada yang Menganiaya diri mereka sendiri dan di antara mereka ada yang pertengahan dan diantara mereka ada (pula) yang lebih dahulu berbuat kebaikan [1260] dengan izin Allah. yang demikian itu adalah karunia yang Amat besar. (QS. Fathir : 32 ).

Menghafal Al-Qur'an merupakan suatu pekerjaan yang sangat mulia. Baik dihadapan manusia, terutama di hadapan Allah SWT. Banyak keutamaan maupun manfaat yang dapat diperoleh dari sang penghafal, baik itu keutamaan yang diperolehnya di dunia maupun di akhirat kelak. Disamping itu pula sang penghafal Al-Qur'an sangat memegang peranan penting dalam menjaga kemurnian dan keaslian Al-Qur'an hingga akhir zaman. ${ }^{3}$

Jadi pada dasarnya menghafal itu mudah, yang susah adalah menjaga dan mempertahankan hafalan yang sudah kita miliki agar jangan sampai hilang atau lupa, karena inilah tantangan yang terbesar yang dihadapi dan dialami semua penghafal AlQur'an. Sebagaimana hadist Nabi Muhammad SAW:

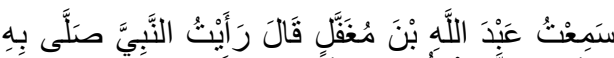

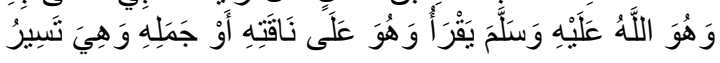

1Syakir Ridwan (2000), Study Al-Qur'an, Unit Tahfid Madrasatul Qur'an, Tebuireng-Jombang, h. 1

2Muhammad Syaifudin, dkk (2003), AlQur'an penyejuk kehidupan, Putra Jaya, Surabaya h.50 3Ilham Agus Sugianto (2004) Kiat Praktis Menghafal Al-Qur'an, Mujahid Press, Bandung,h. 31

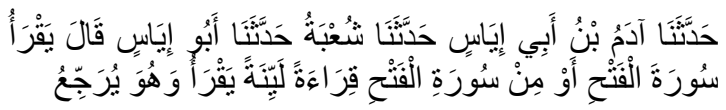

Artinya: Aku pernah melihat Nabi membaca saat beliau berada di atas Untanya yg berjalan, ketika itu beliau membaca surat $\mathrm{Al}$ Fath atau bagian dari surat Al Fath, yakni dgn bacaan yg pelan seraya mengulang-ngulangnya. (HR. Bukhari.)".4

Dalam dunia proses belajar mengajar (PBM), metode jauh lebih penting dari materi. Demikian urgennya metode dalam proses pendidikan dan pengajaran. Sebuah proses belajar mengajar bisa dikatakan tidak berhasil bila dalam proses tersebut tidak menggunakan metode. Karena metode menempati posisi kedua terpenting setelah tujuan dari sederetan komponen-komponen pembelajaran: tujuan, metode, materi, media dan evaluasi. $^{5}$

Sebuah metode dikatakan baik dan efektif manakala bisa mengantar kepada tujuan yang dimaksud. Begitupun dalam menghafal Al-Qur'an, metode yang baik akan berpengaruh kuat terhadap proses hifzhulQur'an, sehingga tercipta keberhasilan dalam menghafal Al-Qur'an.

Metode Takrir adalah salah suatu cara agar informasi - informasi yang masuk ke memori jangka pendek dapat langsung ke memori jangka panjang adalah dengan pengulangan (rehearsal atau takrir), dan merupakan salah satu metode dalam menghafal Al-Qur'an. Peneliti berkeyakinan bahwa metode Takrir sangat penting dalam menghafal Al-Qur'an, karena tanpa proses Takrir (mengulang ulang bacaan) mustahil dapat langsung menghafal Al-Qur'an. Oleh karena itu semakin seringmentakrir bacaan akan semakin mudah menghafalnya. ${ }^{6}$

Metode ini dilatar belakangi oleh banyaknya keluhan dari teman-teman, baik

4Departemen Penerjemah Hadist(2004), Metode Praktis Menghafal Al-Qur'an, Pustaka Azzam. Jakarta, h. 178

${ }^{5}$ Armai Arief (2002) Pengantar Ilmu dan Metodologi Pendidikan Islam, Ciputat Press, Jakarta, h109

6Muhammad Subhan (2004) .metode ilmu pendidikan Islam, Biro penerbit dan penegembangan ilmiah, Gresik, h.60 
yang sedang manghafalAl-Quran maupun yang sudah hatamAl-Quran, mereka merasa kesulitan dalam menghafal dan melancarkan Al-Qur'an. Pondok pesantren Punggul Bagor Nganjuk adalah suatu lembaga pendidikan yang menjadi pusat pendidkan,salah satunya untuk menghafal Al-Qur'an, mendalami dan mengamalkan isi kandungan Al-Qur'an.

Pondok Pesantren Punggul Bagor Nganjuk merupakan salah satu pondok pesantren di wilayah nganjuk yang membuka kesempatan bagi generasi muda Islam untuk belajar tahfidzul Qur'an.Untuk mencapai suatu tujuan teresebut diperlukan strategi atau cara yang jitu dan sesuai dengan yang di butuhkan,Sehingga tujuan yang diinginkan dapat tercapai. Demikian pula denganpelaksanaanmenghafal Al-Qur'an, diperlukanstrategiataumetode yang memudahkanuntukmencapaihasildenganm aksimal.Pondok pesantren Punggul Bagor Nganjuk dalam mengahafal Al-Qur'an menggunakan metode takrir,metode ini di rasa amat gampang dan memudahkan santri untuk menggunakannya, karena dilakukan bersama-sama sehingga semangat santri akan meningkat.

Penulis telah melakukan observasi terhadap santri-santri yang belajar tahfidzdi Pondok Pesantren Punggul Bagor Nganjukdan memperoleh hasil bahwa,para santri telah menggunakan metode tersebut dalam pelaksanaan hafalan mereka.

Berdasarkan latar belakang tersebut, penulis menyusun sebuah Tesis dengan judul: "Implementasi Metode Takrir dalam Menghafalkan Al-Quran bagi Santri Pondok Pesantren Punggul Nganjuk."

\section{Metode-metode dalam menghafal Al- Qur'an}

Dibawah ini akan di uraikan tentang metode -metode yang familier,metodeyangsecara khusus sering diterapkan dan lazim digunakan dalam menghafal Al-Qur'an yaitu:

\section{Metode Tahfidz}

Yang dimaksud metode ini,dimana sebelum penghafal menyetorkan hafalannya pada kyai,kepada mudhir,mustahik atau kepada seseorang yang telah di otoritas untuk menyimaknya,maka penghafal harus melafalkan sebelum disimakkan pada kyai,mudhir dan lain-lain, sebagaimana penjelasan berikut:

a. Terlebih dahulu penghafal melihat mushaf (bin nadzar) sebelum disetorkan pada kyai tentang materi hafalannya.

b. Setelah di baca dengan melihat pada mushaf dan terus ada bayangan,kemudian di baca dengan tanpa melihat mushaf minimal 3 kali dalam satu kalimat, dan maksimal tidak terbatas. Apabila tidak ada bayangan maka harus ditingkatkan sampai menjadi hafal betul.

c. Apabila dalam satu kalimat itu sudah ada bayangan,maka di tambah lagi hafalannya sehingga sempurna menjadi satu ayat. Materi-materi baru ini selalu dihafalkan sebagaimana penghafal dalam materi pertama tadi, kemudian mengulang-ualng kembali pada hafalan yang udah terlewati, minimal empat kali maksimal tidak terbatas sampai benar-benar hafal.Apabila dalam satu materi itu tidak hafal,maka tidak boleh pindah pada meteri berikutnya.

d. Setelah materi satu ayat ini dikuasai hafalannya dengan hafalan yang benarbenar lancar, maka diteruskan dengan menambah materi baru dengan membaca atau melihat(bin nadzar) terlebih dahulu dan mengulang seperti pada materi pertama. Setelah ada bayangan lalu dilanjutkan dengan membaca tanpa melihat sampai benarbenar hafal sebagaimana menghafal ayat pertama.

e. Sesudah mendapat hafalan ayat dengan baik dan lancar tidak terdapat kesalahan lagi, maka hafalan tersebut diulang-ulang mulai dari ayat pertama ditingkatkan ke-2 minimal 3 kali dan maksimal tidak terbatas. Begitu pula ketika menginjak ayat-ayat berikutnya sampai ke batas waktu yang telah ditargetkan. 
f. Setelah materi yang ditentukan menjadi hafal dengan baik dan lancar, kemudian disetorkan pada kyai atau kepada orang yang di beri otoritas untuk disimakkan hafalannya serta mendapatksn petunjuk-petunjuk dan bimbingan seperlunya.

g. Pada hari kedua,penghafal mengajukan hafalan barunya kepada kyai atau kepada orang yang di beri wewenang dan seterusnya. ${ }^{7}$

\section{Metode Wahdah}

Yang dimaksud dengan metode ini,yaitu menghafal satu persatu terhadap ayat-ayat yang hendak dihafalkannya. Sebagai awal, setiap ayat dibaca sepuluh kali atau lebih,sehingga proses ini mampu membentuk pola dalam bayangannya.

Setelah benar-benar hafal barulah dilanjutkan pada ayat-ayat berikutnya dengan cara yang sama,demikian seterusnya hingga mencapai satu muka dengan gerak reflek pada lisannya. Setelah itu dilanjutkan membaca dan mengulangulang lembar tersebut hingga benarbenarlisan mampu memproduksi ayatayat dalam satu muka tersebut secara alami,atau reflek dan akhirnya akan membentuk hafalan yang representatif. ${ }^{8}$

\section{Metode Kitabah}

Kitabah artinya menulis. Metode ini memberikan alternatif lain daripada metode yang pertama. Pada metode ini penulis terlebih dahulu menulis ayat-ayat yang akan dihafalnya pada secarik kertas yang telah disediakan untuknya. Kemudian ayat-ayat tersebut dibacanya sehingga lancar dan benar bacaannya, lalu dihafalkannya.Menghafalnya bisa juga dengan

metodewahdahataudenganberkali-

kalimenuliskannya sehingga dengan berkali-kalimenuliskannya iadapat sambil

7Metode Menghafal Al-Qur'an (2009), Strategi Belajar Mengajar ,Teras, Yogyakarta, hal. 1

8 Muhaimin Zubaid (1996), bimbingan praktis menghafal al-qur'an, pustaka al-husna baru. Jakarta, h. 249 memperhatikan dan sambil menghafalnya dalamhati. ${ }^{9}$

\section{Metode Gabungan}

Metodeinimerupakangabunganantar a metode pertama dan kedua, yaknimetodewahdahdanmetodekitabah.H anyasajakitabah(manulis)di sini lebih memiliki fungsional sebagai uji coba terhadap ayat-ayatyang telah dihafalnya. Maka dalamhal ini, setelah penghafal selesai menghafal ayat yangdihafalnya, kemudian iamencoba menulisnya di atas kertas yang telah disediakan untuknya dengan hafalan pula.

Setelah ia telah mampu mereproduksi kembali ayat-ayat yang dihafalnyadalam bentuktulisan, makaiamelanjutkan kembali untukmenghafalayat-ayatberikutnya, tetapi jika penghafal belum mampu, mereproduksi hafalannya kedalam tulisan secara baik, makaiakembali menghafalkannya sehingga ia benar-benar mencapai nilai hafalan yang valid. ${ }^{10}$

\section{Metode Jama'}

ialah Yang dimaksud dengan metode ini, dilakukansecarakolektif,yakniayat-ayat yang dihafaldibacasecara kolektif, atau bersama-sama, dipimpin oleh seorang instruktur/ guru. ${ }^{11}$

\section{Metode Talaqqi}

Talaqqi artinya belajar secara langsung kepada seseorang yang ahli dalammembacaAl-

Qur'an.Metodeiniyanglebihseringdipakaio rang untuk menghafal Al-Qur'an, karena metode ini mencakup dua faktor yang sangat menentukan yaitu adanya kerjasama yang maksimal antara guru dan murid $^{12}$

\footnotetext{
9Ibid h.41

10http://matahari

ppg.blogspot.com/2013/10/metode menghafal AlQur'an.html

${ }^{11}$ Heri Syaifullah (2005) metode menghafal Al-Qur;an, Pekalongan, h.57

${ }^{12}$ Hasan Langgulung (1988), Asas-asas pendidikan Islam, Pustaka Al-Husna, Jakarta, h.54
} 


\section{Metode Jibril}

Pada dasarnya, istilah metode Jibril adalah latarbelakangi perintah Allah SWTkepada Nabi Muhammad SAW untukmengikuti bacaan Al- Qur'an yang telah dibacakan oleh malaikat Jibril, sebagai penyampai wahyu, Allah SWT berfirman Alloh: Artinya: Apabila Kami telah selesai membacakannya Maka ikutilah bacaannya itu. (Q.S. Al-Qiyamah: 18). Berdasarkan ayat diatas, maka intisari teknik dari Metode Jibril adalah taqlidtaqlid(menirukan), yaitu santri menirukan bacaan gurunya. Dengan demikian metode Jibril bersifat teacher-centris, dimana posisi guru sebagai sumber belajar atau pusat informasi dalam proses pembelajaran. Selain itu praktek Malaikat Jibril dalam membacakan ayat- ayat AlQur'an kepada Nabi MuhammadSAW adalah dengan tartil (berdasarkan tajwid yang baikdan benar). Karena itu, metode Jibril juga diilhami oleh kewajiban membaca Al-Qur'an secara tartil, Allah SWT berfirman:

\section{اوزدعليه ورتل القران ترتيلا}

Artinya:Atau lebih dari seperdua itu.dan bacalah Al-Quran itu dengan perlahan-lahan. (QS.Muzammil : 4)

Dan metode Jibril juga di ilhami oleh peristiwa turunnya wahyu secara bertahap yang memberikan kemudahan kepada para sahabat untuk menghafalnya dan memaknai makna-makna yang terkandung didalamnya. ${ }^{13}$

Inti sari teknik dari metode Jibril adalah taqlid-taqlid (menirukan), yaitu murid menirukan bacaan gurunya. Dengan demikianmetode Jibril bersifat teachercentris, dimana posisi guru sebagai sumber belajar atau pusat.

Informasi dalam proses pembelajaran. Metode ini sudah dipakai pada zaman Rasulullah dan para sahabat. Setiap kali Rasulullah SAW menerima wahyu yang berupa ayat-ayat Al-Qur'an, beliau membacanya di depan para sahabat, kemudian para sahabat menghafalkan ayat-ayat tersebut sampai hafal di luar

${ }^{13}$ Ahsin WAl-hafidz (2005), Al-Qur'an di hati, PT. Bumi Aksara, Jakarta, h. 5-6 kepala. Metode yang digunakan Nabi mengajar para sahabat tersebut, dikenal dengan metode belajar kattab. Disamping menyuruh menghafalkan, Nabi menyuruh kattab (penulis wahyu) untuk menuliskan ayat-ayat yang baru diterimanya itu. ${ }^{14}$

\section{Metode Isyarat}

Prinsip dasar metode ini ialah seorang guru, pembimbing dan orang tua memberikan gambaran tentang ayat-ayat Al-Qur'an. Setiap kata dalam setiap ayat AlQur'an memiliki sebuah isyarat. Makna ayat dipindahkan melalui gerakan-gerakan tangan yang sangat sederhana, dengan cara ini anak dengan mudah memahami setiap ayat Al-Qur'an, bahkan dengan mudah menggunakan ayat-ayat tersebut dalam percakapan sehari-hari. Misalnya, untuk menghafal QS. Al-Ikhlas ayat 1 yaitu dengan gerakan tangan kanan dijulurkan ke atas dan membuka jari penunjuk dengan menelangkupkan jari lain (selain jari penunjuk). Dan itu sebagai isyaroh atau petunjuk bahwasannya Tuhan itu hanya satu yaitu Allah SWT.

Menghafal Al-Qur'ah adalah sebuah upaya untuk memudahkan seseorang didalam memahami dan mengingat isi-isi Al-Qur'an dan untuk menjaga keotentikannya serta menjadi sebuah amal saleh, tentunya dalam hal ini perlu metode yang tepat sehingga file hafalan yang disimpan dalam otak manusia bisa tersimpan dengan bagus sehingga hafalannya sangat kuat ${ }^{15}$

\section{Metode Takrir}

Metode ini merupakan suatu metode untuk mengulang-ulang hafalan, Jadi metode takrir ini sangat penting sekali diterapkan, karena menghafalkan serta menjaga hafalan merupakan suatu kegiatan yang sulit dan kadangkala terjadi kebosanan. Sangat dimungkinkan sekali suatu hafalan yang sudah baik dan lancar menjadi tidak lancar atau bahkan menjadi hilang sama sekali. Sewaktu takrir, materi

${ }^{14}$ Amanah (1991), Pengantar Ilmu Al-Qur'an \& Tafsir , As-Syifa, Semarang, h. 104

15Anissatul Mufarrokah (2009), Strategi Belajar Mengajar dengan cepat, Teras, Yogyakarta, h. 1 
yang diperdengarkan kehadapan instruktur harus selalu seimbang dengan tahfidz yang sudah dikuasainya. Jadi tidak boleh terjadi bahwa tahfidz yang telah di hafalkan, jauh ketinggalan dari yang dihafalnya dengan metode Takrir. Tepatnya materi tahfidz satu juz yang terdiri dari dua puluh halaman, maka dalam menghafalkan dengan metode Takrir harus mendapat imbangan sekira tidak memberatkan bagi seorang hafidz, demikian seterusnya. Dan apabila materi satu juz itu sudah mendapat imbangan, umpama tahfidznya sudah mendapat dua puluh halaman, maka kesempatan untuk menghafal Al-Qur'an dengan metode Takrir bisa ditambahkan sesuai dengan kebutuhan.

Takrir sebagian dari proses menghafalkan Al-Qur'an yang juga sebagai kunci keberhasilan dari semua yang diusahakan dalam menghafalkan dan menjaga hafalan Al-Qur`an pada diri seseorang. Menghafalkan Al-Qur'an dengan metode Takrir itu mudah dan efisien, itu harus imbangi dengan usaha pengulangan secara ketat, karena kalau hafalan yang sudah ada tidak akan bertahan lama dan akan sia-sia jikalau pemelihara'an tidak dilaksanakan. Karena hal yang telah dihafalkan tadi akan tertimbun dengan hafalan yang baru dan begitu seterusnya. Sedangkan kunci keberhasilan menghafal Al-Qur`an adalah mengulang-ulang hafalan yang dihafalkannya yang disebut "takrir" 16

\section{Hasil Penelitian}

Implemenentasi Metode Takrir di Pondok Pesantren Punggul

Implenetasi metode Takrir menggunakan beberapa langkah antara lain: a) Maintenance rehearsal, yaitu pengulangan untuk memperbarui ingatan tanpa mengubah struktur (sekedar pengulangan biasa) atau disebut juga pengulangan tanpa berpikir. b) Elaborative rehearsal, yaitu pengulangan yang diorganisasikan dan di proses secara aktif, serta dikembangkan hubungan-

16Mohammad Irwansyah (2009), Strategi menghafal cepat, Pustaka Amani, Yogyakarta, h.1 hubunganya sehingga menjadi sesuatu yang bermakna.

Penerapan metode taqrir ini berarti penyimpanan informasi di dalam gudang memori atau brain dan seberapa lama kekuatanya juga tergantung pada individu. Ada orang yang memiliki daya ingat kuat,sehingga menyimpan infomasi dalam waktu lama,meskipun tidak atau jarang diulang, sementara yang lain memerlukan pengulangan secara berkala bahkan cenderung terus-menerus. Perlu di tegaskan bahwa gudang memori itu tidak akan penuh dengan informasi - infornasi yang di masukan ke dalamnya walaupun disimpan berulang-ulang, kerena kemampuanya menurut para pakar psikologi nyaris tanpa batas. Hanya perlu di ketahui bahwa belahan otak (otak kanan dan otaak kiri) mempunyai fungsi yang berbeda. Fungsi belahan otak kiri terutama untuk menangkap persepsi kognitif, menghafal, berpikir linier dan teratur. Sedangkan belahan otak kanan lebih terkait dengan persepsi imajinatif, dan kreatif.

Metode takrir menjadi solusi yang paling tepat untuk di terapkan di pondok pesantren Punggul karena sesuai dengan keadaan santri yang ada di sana,kebanyakan santri tahfidz pondok Punggul masih bersekolah formal diantaranya masih ada yang SMP dan sederajat, SMA, SMK dan lain-lain. Sehingga dalam kaitannya dengan waktu maka hampir setengah harian penuh waktu mereka dihabiskan di sekolahan mereka masing-masing, yaitu mulai pukul 07.00 pagi sampai pukul 14.00 siang. Dengan fenomena itulah maka menghafal Al-Qur'an di pondok pesantren Punggul dengan menggunakan metode Takrir sangatlah efektif dan efisien. Adapun halhal yang dipaparkan yang berkaitan dengan implementasi metode Takrir untuk menghafal Al-Qur'an bagi santri di pondok pesantren Punggul ,ini merupakan hasil penelitian selama kurang lebih 3 bulan.

Adapun Keunggulan implementasi Metode Takrir di pondok pesantren Punggul adalah sebagai berikut: 
a) metode yang efektif untuk semua santri hal itu di buktikan dengan, ntusiasnya para santri dalam mengikutinya,walaupun belum keseluruhan.b) Metode sangat simpel dan praktis bisa dipahami semua santri, c) Waktu belajar yang singkat, dengan teman banyak sehingga lebih semangat dan kompetitif, d) Proses belajar yang memastikan setiap peserta lancar dan benar membaca Al-Qur'an.

Menurut Yai bahwa metode taqrir merupakan Metode sangat mudah,cepat,dan menyenangkan dalam menghafal Al-Qur'an, dan hampir semua siswa mampu mengafalkan Al-Qur'an secara maksimal.

Dengan demikian maka metode Takrir ini sesuai dengan pendapat yang telah di sampaikan oleh seorang pakar pendidik dan seorang sosilog dari prencis yaitu Jacques Barzun berkata"Dalam mengajar, Anda tidak bisa melihat hasilnya dalam satu hari kerja. Mungkin hasilnya baru kelihatan 20 tahun kemudian." Maka dengan demikian dalam upaya menghafalkan Al-Qur'an maka harus dengan cara kesabaran dan kesungguhan serta niat yang kuat.

Dari berbagai informasi yang telah dipaparkan secara lugas oleh para informan,maka dapat di analisis bahwa ada dua temuan, temuan yang pertama terkait jalan akses untuk menuju pon-pes Punggul masih berupa tanah liat (belum aspal) sehingga untuk menuju ke sana di butuhkan ekstra konsentrasi karena medan yang di tempuh merupakan jalan persawahan yang banyak genangangenangan air dan berlumpur ketika musim penghujan atau ketika saat para petani memulai bercocok tanam dan saat panen, karena intensitas penggunaan jalan akan meningkat sehingga jalan akan mudah rusak karena kelebihan muatan (over kapasitas).

Dan temuan yang kedua adalah terkait sistem yang berjalan di pondok pesantren Punggul khususnya pada program Tahfidznya,dalam sebuah upaya kegiatan KBM itu terdiri dari 2 komponen sistem, yaitu pertama adalah sistem klasikal dan yang kedua adalah sistem modern. Adapun yang dimaksud sistem Klasikal adalah sebuah sistem yang yang mana dalam pembelajarannya masih menggunakan cara-cara yang natural atau alami dan manual,tidak dengan alat-alat yang menggunakan teknologi yang canggih. Sedangkan yang dimaksud dengan sistem modern adalah sebuah sistem KBM yang dalam pembelajarannya menggunakan alat atau sarana prasarana yang canggih. Maka dari itu dalam penelitian ini ditemukan implementasi metode takrir untuk menghafal Al-Qur'an di pondok pesantren Punggul, dalam proses menghafal Al-Qur'an di pondok pesantren Punggul ini, masih menggunakan sistem dan cara tradisional, hal tersebut tidak bisa di pungkiri karena kebanyakan para ustadz yang ada di pondok Punggul ini adalah lulusan atau alumni dari pondok salaf seperti lulusan dari pon-pes Lirboyo, Mojosari, Kremyang, Perak (Jombang) dan lain-lain. Sehingga para ustadz dalam mengajar para santri di pon-pes Punggul juga menggunakan metode-metode yang meraka dapatkan dari pondok mereka masing-masing, kemudian mereka terapkan di pon-pes Punggul. Saya selaku peneliti setuju dengan cara mereka hal tersebut bertujuan untuk tetap menjaga tradisi pondok-pondok salaf di Nusantara agar tetap eksis dan survive dalam perubahan zaman, selain itu untuk menangkal menepis dan menyanggah sebuah anggapan bahwa pondok pesantren adalah bukan gudangnya paham radikal yang semakin marak di tahun-tahun ini, hal ini sesuai dengan pernyataan yang telah di ungkapkan oleh al-mukarom KH.Hasyim Muzadi," pondok pesantren tidak mengenal istilah radikal dan bukan pula sarang teroris" Dan untuk menyangkal anggapan kebanyakan orang yang menilai bahwa pon-pes adalah sebuah lembaga yang termaginalkan maka seyogyanya pon-pes dalam pembelajarannya juga menggunakan perangkat elektronik seperti menggunakan perangkat komputer dan lain-lain, agar lulusan pondok bisa bersaing secara kompetitif dengan lulusan-lulusan sekolah 
formal/sekolah modern ,dengan demikian maka di satu sisi pon-pes tetap mempertahankan kesalafannya dan di satu sisi pon-pes tidak ketinggalan zaman, tidak gaptek dan tidak termaginalkan.

Dari wawancara dari berbagai narasumber mengenai menghafal $\mathrm{Al}$ Qur'an dengan cara dibaca bersama-sama dan diulang-ulang sesuai dengan batasan yang ditentukan sesuai dengan keterangan di atas,maka dapat diambil kesimpulan bahwasanya terkait menghafalkan AlQur'an di pon-pes Punggul benar dengan menggunakan cara dibaca bersama-sama dan diulang-ulang sesuai dengan batasan yang telah ditentukan oleh seorang ustadz, saya selaku penulis setuju dengan metode membaca bersama yang di laukukan oleh ustadz - ustadz tahfidz yang ada di pondok pesantren Punggul, hal itu akan mendatangkan beberapa manfaat dan keunggulan diantaranya, yang pertama adalah santri akan menjadi lebih semangat karena mengingat teman-temannya banyak, kedua ustadz akan menjadi mudah untuk mengamati bacaan para santrisantrinya, hal tersebut sesuai dengan landasan pendidikan yang telah dicetuskan oleh Ki Hajjar Dewantara, yang dinyatakan dengan ungkapan "ing ngarso sung thulodo, ing madyo mangun karso, tut wuri handayani" 17 , yang artinya adalah di depan memberi contoh, di tengah membimbing dan di belakang memberi semangat. Dengan demikian maka apa yang telah di lakukan oleh para ustadz di pondok pesantren Punggul itu, jika di lihat dari sudut pandang pendidikan maka mereka telah mengamalkan nilai-nilai luhur yang telah ditanamkan oleh Ki Hajjar Dewantara yaitu para ustadz pertama memberikan contoh kemudian membimbing dan memberikan semangat kepada para santri. Dan menurut Colin Powel" Tidak ada rahasia untuk sukses. Ini adalah hasil sebuah persiapan, kerja keras, dan belajar dari kesalahan." Jadi dengan demikian maka bisa disimpulkan tidak ada kata tidak bisa, tidak ada kesuksesan tanpa kerja keras.

${ }^{17}$ Gunarsa dkk (2008), Psikologi Remaja, Raja Wali Press, Jakarta, h. 124-125
Dari beberapa Nara sumber di atas maka bisa disimpulkan, semua santri tahfidz setelah selesai membaca Al-Qur'an bersama-sama selama waktu yang telah ditentukan dan jumlah pengulangan yang telah ditentukan maka oleh ustadz Nadzir atau ustadz Nasrudin santri disuruh untuk mengulang hafalnnya dengan bergiliran setra tanpa melihat Al-Qur'annya, dan bagi santri yang sudah lancar maka dia tidak mengulang hafalannya akan tetapi bagi santri yang belum lancar maka akan disuruh mengulang oleh ustadznya, sampai dirasa semua lancar. Dengan demikian maka menghafal Al-Qur'an di pondok pesantren Punggul termasuk pendidikan otoriter, yang dimaksud dengan pendidikan otoriter menurut Mahfudh Shalahuddin "Pendidikan yang mana anak senantiasa mengikuti apa yang disuruh oleh seorang guru." 18

Dari berbagai keterang dari informan di atas maka dapat di simpulkan bahwa para santri melakukan murajaah hafalannya setiap hari kecuali hari jum'at dilakukan setelah jamaah shalat subuh kemudian para santri melakukan tahfidz bil goib dalam satu majlis yang dilakuakan sekiar jam 04.00 sore, dengan demikian maka ada tiga hal pokok yang rutin dilakukan oleh para santri tahfidz, pertama para santri melakukan tahfidz dengan metode Takrir, kedua para santri melakukan murajaah seusai shalat Subuh, dan yang ketiga para santri melakukan tahfidz bil goib dalam satu majlis. Menurut Confucius seorang filosof dan seorang psaikolg dari China berkata "Saya mendengar dan saya lupa. Saya melihat dan saya ingat. Saya lakukan dan saya paham."19 dengan itu maka murajaah sangatlah diperlukan untuk mengingatingat hafalan yang telah dihafalkannya.

\section{Hasil yang telah di Capai}

Dari ulasan keterang yang diambil dari beberapa informan di atas maka dapat di simpulkan bahwa kegiatan tahfidzul

\footnotetext{
18Mahfudh Shalahuddin (1986), Pengantar Psikologi Umum, Sinar Wijaya, Surabaya, h. 49 ${ }^{19}$ David Smith (1983), Remambering Pustaka, Indah, Jakarta, h. 122
} 
qur'an di pondok pesantren Punggul secara keseluruhan telah berhasil, mengingat kegiatan santri padat yaitu selain para santri menghafal Al-Qur'an, mereka sebagian besar juga sekolah formal, sebagai indikasi keberhasilan santri adalah para santri bisa mengulang hafalannya setengah juz setiap bulan, sesuai dengan tarjet yang telah ditentukan oleh lembaga, dan bagi para santri yang bisa hafal Al-Qur'an 5 juz ke atas akan diikutkan event-event yang berkenaan dengan kegiatan tahfidzul qur'an, sperti mengikuti semaan Al-Qur'an di kecamatan Wilangan yang rutin di lakukan setiap selapan sekali dan acara rutinann Al-Qur'an malam 29 Ramadhan di masjid Baiturrahim Manggarejo, dengan indikasi-indikasi di atas maka menghafalkan Al-Qur'an dengan metode Takrir bisa dilakukan secara beriringan dengan kegiatan lainnya seperti sekolah formal, dan itu terbukti efektif.

Dari berbagai keterangan yang telah dipaparkan oleh para informan maka dapat disimpulkan bahwa praktek evaluasi implementasi metode Takrir untuk menghafalkan Al-Qur'an tetap dilakukan kendati tarafnya masih kecil, artinya dalam musyawarah masih dilakukan secara individual yaitu antara ustadz satu dengan ustadz yang lainnya atau ustadz dengan duriyah saja sehingga dalam musyarah itu, belum melibatkan semua elemen kayak banyak seperti melibatkan santri, tokoh masyarakat, masyarakat, wali santri, dan lain-lain, selain itu jika ada musyawarah itupun dirasa terlalu lama dan terlalu jarang dilakukan yaitu satu tahun hanya 2 kali, yang dilakukan tiap 6 bulan sekali, hal tersebut menurut saya sebagai penulis, kurang efektif dan efisien alasanya jeda waktunya terlalu lama sehingga hal tersebut akan menyebabkan intensitas pertemnuan untuk membahas, memaparkan hal-hal yang sudah tercapai, yang belum tercapai, gagasan-gagasan untuk mencapai tujuan yang belum tercapai, bagaimana penerapannya, kendala-kendala yang dihadapi baik dari santri maupun ustadz, dan lain-lainnya, yang mana untuk memecahkan semua itu tidak cukup untuk dipecahkan oleh perseorangan atau hanya dengan kelompok kecil melainkan harus dilakukan dengan musyawarah yang sifatnya besar dan menyeluruh, merangkul semua komponen serta tidak ada intimidasi, oleh karena itu saya sebagai penulis setuju dengan gagasan yang telah disodorkan oleh bapak Masdar, jadi untuk musyawarahnya dilakukan 2 bulan atau 3 bulan sekali sesuai kebutuhan dan untuk semua santri diberikan kartu prestasi hal itu bertujuan untuk mengetahui dan memonitor tingkat prestasi para santri baik santri tahfidz atau santri diniyah.

\section{Kesimpulan}

Berdasarkan hasil analisis di atas yang telah diuraikan yaitu yang berkenaan tentang implementasi metode Takrir dalam menghafalkan Al-Qur'an bagi santri di pondok pesantren Punggul Nganjuk tahun 2017, maka dapat kita ambil kesimpulan: 1) Implemenentasi Metode Takrir di Pondok Pesantren Punggul, 2) hasil penerpan metode taqriri pondok pesantren Punggul Bagor Nganjuk, dapat dengan dengan mudah santri mengingat kembali, artinya dapat mempertajam ingantan santri dalam menghafal $\mathrm{Al}$ Qur'an.

\section{Daftar Pustaka}

Shihab, Quraish (1998), Wawasan AlQur'an, Bandung: Mizan Press

Sa'dulloh (2008), 9 Cara Praktis Menghafal Al-Qur'an, Jakarta: Gema Insani

Ridwan, Syakir (2000), Study Al-Qur'an, Jombang: Unit Tahfid Madrasatul Qur'an

Muhammad Syaifudin, dkk (2003), AlQur'an penyejuk kehidupan, Surabaya : Putra Jaya,.

Basthul B, Maftuh (2010), 100 tanya jawab Al-Qur'an,MMQ Kediri: Lirboyo,

Sugianto, Agus, Ilham (2004) Kiat Praktis Menghafal Al-Qur'an, Bandung: Mujahid Press, 
Departemen Penerjemah Hadist (2004), Metode Praktis Menghafal AlQur'an, Jakarta: Pustaka Azzam.

Armai, Arief (2002) Pengantar Ilmu dan Metodologi Pendidikan Islam Jakarta: Ciputat Press

Subhan, Muhammad (2004). metode ilmu pendidikan Islam, Gresik: Biro penerbit dan pengembangan ilmiah,

Rochidin, Wahab (2004). Sejarah Pendidikan Islam di Indonesia, Bandung: Alfabeta

Irfan, Hielmy (2000) Wancana Islam, Ciamis: Pusat Informasi Pesantren

Fatah, H, Rohadi Abdul (2005), Rekontruksi Pesantren Masa Depan, Jakarta: PT. Listafariska Putra

HS, Mastuki, El-sha, M. Ishom (2006) Intelektualisme Pesantren, Jakarta: Diva Pustaka

Haedari, H. Amin (2007), Transformasi Pesantren, Jakarta: Media Nusantara

Fuad, Anwar (2009) Majalah Tajdid Ciamis: Lembaga Penelitian dan Pengembangan,

Subhan, dkk (2012) Potret Pesantren Pena Santri, Kediri,

Dhofier Zamakhsyari (1983) Tradisi Pesantren, LP3ES, Jakarta.

Subhan, Muhammad (2014), menelusuri sudut-sudut dan peran pesantren sebagai lembaga pendidikan tertua, Surakarta: Pena Santri.

Hasbullah (2001) Sejarah Pendidikan Islam Di Indonesia, PT Raja Grafindo, Jakarta.

Harahab,Husain (2004) Perjuangan Santri, Bandung: Bina Karya,

Shaleh, Abdurrahman Menggerakkan Tradisi, Esai Pesantren,

Amin, Rais (1989) Cakrawala Islam Antara Cita Dan Fakta, Bandung: Mizan,.

Abas, Ibnu (1988)Pondok Cemerlang, Yogyakarta: Menara Agama,

Ahmadi, Abu (2006), Ilmu pendidikan Islam, Jakarta: PT. Rineka Cipta,

Uhbiyati, Nur (2006), Pesantren Tradisional, Pustaka Jaya, Jakarta.
Siregar, Suryadi (1996) Pondok Pesantren Sebagai Model Pendidikan Tinggi. Bandung.: Kampus STMIK

Al-Fairuz abadi (2015), Al-Qamus Almuhith, Surakarta. Al-qowam,

Az-Zarqani, Abdul (2013), Manahil Al-Irfan, j. I, Surabaya. Al-alam,

Al-asom, Aziz (1997), ullumul kalam, Yogyakarta. Pustaka ilmu,

Ilham, Saiful (2002), Al-Qur'an gemilang, Citra galery, Bandung.

Al-Qaisi (1998), Lentera Al-Qur'an, Jakarta. Puspa merdeka,

Zen, Muhaimin (1996), bimbingan praktis menghafal al-qur'an Jakarta: Pustakaal-husna baru.

Ramayulis (2006), bimbingan praktis menghafal al-qur'an, Jakarta: Kalam Mulia

Shalahuddin, Mahfudh (1996), Kiat-kiat seorang Hafidz, Sinar Wijaya, Surabaya.

Metode Menghafal Al-Qur'an (2009), Strategi Belajar Mengajar Teras, Yogyakarta.

Zubaid, Muhaimin (1996), bimbingan praktis menghafal al-qur'an, Jakarta. Pustaka al-husna baru.

Al-hafidz, Ahsan (2005), Al-Qur'an di hati, Jakarta. PT. Bumi Aksara,

Amanah (1991), Pengantar Ilmu Al-Qur'an \& Tafsir, Semarang. As-Syifa,

Langgulung, Hasan (1988), Asas-asas pendidikan Islam, Jakarta. Pustaka Al-Husna,

Mufarrokah, Anissatul (2009), Strategi Belajar Mengajar dengan cepat, Yogyakarta. Teras,

Irwansyah, Muhammad (2009), Strategi menghafal cepat, Yogyakarta. Pustaka Amani,

Arifin Ilham, Muhammad (1996), Ilmu Pendidikan Al-Qur'an, Jakarta. Bumi Aksara,

Departemen Pendidikan Dan Kebudayaan (1995), Kamus Besar Bahasa Indonesia, Jakarta: Balai Pustaka,

Bahri Djamarah, Saiful (2002), Ulummul Qur'an, Jakarta: PT. Rajawali Press,

Munawir (1984) Al-Munawi bil kaifiyahr, Bandung: Pustaka mandar maju, 